\title{
Franciszek Rapacki
}

\section{Zarys historii obrządków wschodnich na północnych obszarach Królestwa Węgier}

Z

amieszkane przez Słowian północne ziemie dawnego Królestwa Węgier, które rozdzielone są dziś pomiędzy Słowację i Ukrainę, przez wieki pozostawały pod wpływem kultury wschodniej. Także dziś ludność na ziemiach Rusi Zakarpackiej (czy jak chce historiografia węgierska i niegdyś czechosłowacka: Podkarpackiej) oraz na niemałym obszarze Słowacji przynależy do Kościołów wschodnich. Najdalej wysunięta na zachód greckokatolicka parafia znajduje się w spiskiej miejscowości Osturnia, zaledwie 20 kilometrów od polskiego Zakopanego.

Geneza wschodnich obrządków na omawianym obszarze nie jest sprawą jednoznaczną i pozostaje przedmiotem sporu uczonych węgierskich, ukraińskich oraz badaczy o tożsamości rusińskiej. Poniższy artykuł referuje przede wszystkim stanowisko badaczy rusińskich, tj. podkreślających odrębność tradycyjnej ludności Zakarpacia i części górskich rejonów Polski i Słowacji. W tekście zaznaczone są wątpliwości dotyczące dyskusyjnych i trudnych do zweryfikowania sądów, szczególnie odnoszących się do czasów średniowiecza.

Nie ulega wątpliwości, że początki słowiańskiego obrządku (a więc obrządku innego niż ten kształtujący się w kręgu kultury łacińskiej - używającego innego języka, alfabetu, częściowo związanego z innymi zwyczajami i praktykami religijnymi) na terenach pod Karpatami wiążą się z czasami Państwa Wielkomorawskiego (w przypadku zachodnich i centralnych terenów współczesnej Słowacji). Według mitycznych interpretacji przywoływanych przez historiografów rusińskich, chrześcijaństwo powiązane ze słowiańskim obrządkiem pojawiło się na południowych stokach Karpat wraz z misją św. Cyryla i Metodego, a więc już od około 863 roku [Magocsi, Pop 2005: 78]. Należy przy tym nadmienić, że Kościół metodiański mimo słowiańskiej liturgii był powiązany z Rzymem i trudno go bezpośrednio łączyć z późniejszym prawosławiem [Leśny 1987: 46]. Badacze rusińscy wskazują też wpływy Rusi Kijowskiej i jej relacje z ziemiami Rusi Podkarpackiej i wschodniej Słowacji, ale takie oddziaływania wydają się dyskusyjne ${ }^{2}$. Na koniec IX wieku (896 rok) przypada natomiast - w powszechnej

\footnotetext{
${ }^{1}$ Słowiańskie enklawy znajdują się również w północnych rejonach Węgier i Rumunii, przede wszystkim w rumuńskim okręgu Maramuresz.

${ }^{2}$ Rozważania takie nie są głównym tematem artykułu, więcej o problematyce wczesnego chrześcijaństwa na omawianych ziemiach: Gerard Labuda, Szkice historyczne X-XI wieku, Poznań 2004; Gerard Labuda, Studia nad poczq̨tkami państwa polskiego, t. 2, Poznań 1988; Jan Leśny, Konstantyn i Metody apostołowie Słowian. Dzieło i jego losy, Poznań 1987.
} 
opinii badaczy przedmiotu - pojawienie się Madziarów w Kotlinie Panońskiej, a początek państwowości węgierskiej nastąpił wraz z koronacją króla Stefana I w roku 1001³. Według przedstawicieli nurtu badawczego związanego z Rusinami, w węgierskim organizmie państwowym rozpoczął się wówczas proces wypierania dominującej słowiańskiej liturgii przez obrządek łaciński, choć miał on być stosunkowo powolny 4 .

Zdaniem niektórych badaczy na północnych terenach Węgier wpływy łacinników zaczęły rosnąć dopiero w początkach wieku XIII, gdy w efekcie czwartej wyprawy krzyżowej (w 1204 roku) podbito Konstantynopol - wcześniej więzi ze Wschodem były na tyle silne, że madziarska dynastia Arpadów zwykła zawierać małżeństwa z przedstawicielami rodów słowiańskich i greckich [Timkevič 2004: 216], a król Koloman Uczony (rządzący w latach 1098-1116) aż do czasu koronacji miał być mnichem w bazyliańskim klasztorze w Waradynie (sic!). Sytuację znacząco zmieniał przede wszystkim Sobór Laterański z 1215 roku, ustanawiający prymat hierarchów obrządku łacińskiego (nie zezwalał na istnienie dwóch biskupstw w jednym okręgu), a proces przyspieszyły następujące po nim nakazy władz kościelnych (m.in. papieskie bulle, w których domagano się od królów węgierskich rugowania słowiańszczyzny z kościołów) [Timkevič 2004: 258-259, 887]5.

W przypadku Królestwa Węgier i losów wschodnich obrządków na jego terytorium, szczególnie ważną cezurę wyznacza 1241 rok. Niemiecki kronikarz odnotował: „,W tym roku państwo węgierskie po trzystu pięćdziesięciu latach istnienia zostało zniszczone przez Tatarów" [Felczak 1966: 44]. W odbudowującym się po najeździe Batu-chana Królestwie nastąpiły znaczące zmiany, w tym pojawienie się nowego typu kolonizacji (na prawie niemieckim), dalsze wzmacnianie władzy szlachty oraz znaczące rozszerzenie wpływów zachodnich związane z wygaśnięciem lokalnej dynastii Arpadów (w 1301 roku) i przejęciem władzy przez neapolitańską linię francuskich Andegawenów (m.in. rozwinęły się wówczas powstałe krótko przed najazdem misje franciszkańskie - to właśnie franciszkanie zajmowali się w Kościele katolickim pracą misyjną) [Timkevič 2004: 301]. Jednocześnie na fali

\footnotetext{
${ }^{3}$ Interesujące nas komitaty północnych Węgier, które z czasem miały się ukształtować na północy Królestwa, to przede wszystkim Marmarosz, Ugocza Bereg, Ung, Zemplin, Szarisz, Spisz, ale też Szatmar, Szabolcs, Abow, Borszod, Gemer, Turnia, a nawet Liptów czy Orawa.

${ }^{4}$ Na osobną wzmiankę zasługuje problem bizantyjskich wpływów na ziemiach Węgier - misji czy obecności klasztorów podległych Konstantynopolowi [Zob. Györffy 2003]. Warto też pamiętać, że kolonizacja najdzikszych terenów w północno-wschodnim rejonie kotliny karpackiej i docieranie tam władzy panów węgierskich trwały aż do XIII wieku. Nie jest wykluczony wpływ na te tereny bizantyjskich klasztorów z południowych Węgier.

${ }^{5}$ Przywoływany przez Timkeviča XIX-wieczny badacz, pracownik Macierzy Słowackiej i rzymskokatolicki ksiądz Franciszek Sasinek dowodził wręcz, że w centralnych Węgrzech większość stanowiły wówczas klasztory słowiańskie, co potwierdzać miały papieskie bulle. Nawet centralne biskupstwo ostrzyhomskie zostało w jednej z nich wskazane jako miejsce, gdzie powinna zajść zmiana języka liturgii z cerkiewnosłowiańskiego na łacinę. Sándor Bonkáló uważa, że ruską grupę na terenie Węgier stanowiła początkowo przede wszystkim świta wchodzących w związki dynastyczne z Arapadami kniaziów i księżnych. Z Rusi Halickiej trafiały też na Węgry pewne grupy prowęgierskich bojarów i żołnierzy bądź też jeńcy wojenni - stosunki Węgier i Rusi były na przemian przyjacielskie i wrogie [Bonkáló 1990: 10].
} 
nowych procesów osadniczych, począwszy od wieku XIV, pojawiły się też w Karpatach migracje silnie powiązane z tzw. „Starą Wiarą”, tj. wpływami bizantyjskimi - była to tzw. kolonizacja na prawie wołoskim. Wzdłuż łuku Karpat od strony Bałkanów ruszyła wielka fala osadników trudniących się na co dzień pasterstwem.

Do ludności pochodzenia bałkańskiego i rumuńskiego dołączali po drodze Rusini (prawdopodobnie haliccy) ${ }^{6}$. Jak dowodzi węgierska badaczka Adrienne Körmendy, wołoscy zasadźcy (kniaziowie) mieli prawo zakładać swe miejscowości jedynie w górach, ponad obszarami urodzajnej ziemi, a to skutecznie izolowało kolonizatorów od innych grup etnicznych7. Zasadźcom przysługiwało też m.in. prawo do „pozyskiwania” na potrzeby wsi duchownych obrządku wschodniego. W praktyce tacy kapłani pozostawali poza jurysdykcją kościelną, a funkcje religijne na ogół były wśród nich dziedziczne. Jozafát V. Timkevič wskazuje na podział duchowieństwa wschodniego północnych Węgier na dwie grupy: tzw. księży czarnych - związanych z regułą zakonu Bazylianów - i księży białych, czyli nieposiadającą pełni praw ludność (przede wszystkim wiejską, zmuszoną do płacenia czynszów), która przynależność do stanu duchownego przekazywała właśnie z pokolenia na pokolenie, przyjmując święcenia (zdaniem badacza często w sekrecie lub za cichą zgodą właścicieli ziemskich, wbrew formalnemu zakazowi) w czasie okolicznościowych uroczystości w monastyrach [Timkevič 2004: 79 i dal.].

Istnieje niewiele dokumentów potwierdzających funkcjonowanie związanych ze Wschodem centrów religijnych na północnych obszarach Królestwa bezpośrednio po najeździe tatarskim. Nie ma też źródeł poświadczających istnienie bazyliańskich monastyrów. Wyjątek stanowić może jedynie funkcjonujący w komitacie Marmarosz zależny bezpośrednio od patriarchy Konstantynopola monastyr Uholski (Połoniński). Zdaniem rusińskich badaczy wzmiankowany był on przez latopis halicko-wołyński już w 1262 roku [Magocsi, Pop 2005: 507], jednak zapis kronikarski takiego faktu nie przesądza [por. http:// litopys.org.ua/litop/lit25.htm]. Dopiero z końca XIV wieku (1392 rok) pochodzą pierwsze źródła informujące o istnieniu monastyru św. Mikołaja na Czarnej Górze pod Mukaczewem, czyli o miejscu, które stało się już w początkach wieku XV centrum Kościoła wschodniego w północnych Węgrzech, a tutejszy archimandryta ogłaszany był jednocześnie patriarchą wszystkich Rusinów Królestwa.

${ }^{6}$ Problem migracji wołoskich jest interpretowany także w inny sposób. Rusińscy badacze (np. Jozafát V. Timkevič) podważają decydującą rolę zlatynizowanego żywiołu wołoskiego i stawiają tezę, że decyzje Kościoła z 1215 roku oraz rosnące przywileje średniej szlachty (w tym Złota Bulla Karola II z 1222 roku) wpłynęły na przenoszenie się ruskiej ludności centralnych Węgier na tereny górskie - tu można było częściowo zachować wolność osobistą, zajmując się pasterstwem, a przy tym pozostać przy swoim wyznaniu. Badacze ukraińscy uważają z kolei, że podstawę fali osadniczej stanowili - również szukający wolności osobistej - chłopi haliccy.

${ }^{7}$ Na podstawie informacji uzyskanych od Adrienne Körmendy w ramach konsultacji w Katedrze Hungarystyki Uniwersytetu Warszawskiego. 
Artykuły

Odnotować należy, że to właśnie z Czarną Górą związany jest jeden z najważniejszych mitów Rusinów karpackich (dla lokalnych ukrainofilów to w istocie rzeczy mit założycielski) i ich Kościoła. Mowa tu o przeprawie przez Karpaty księcia Fiodora Koriatowycza z terenów litewskiego wówczas Podola. Do dziś w licznych źródłach w oparciu o rzekomy akt fundacji monastyru pod Mukaczewem nazywa się Koriatowycza księciem i właścicielem miasta i podaje się liczbę 50 tys. żołnierzy, którzy dotarli z Podola do północno-wschodniego krańca Królestwa Węgier. Jako datę całego zdarzenia wskazuje się rok 1360, a klasztor mukaczewski miał być właśnie fundacją Koriatowycza. W rzeczywistości dokumenty wskazują, że podolski kniaź dotarł tu dopiero ok. roku 1400 i jego wpływy były niewielkie. Sam akt fundacji monastyru na Czarnej Górze uznawany jest dziś powszechnie za fałszerstwo dokonane w klasztorze w późniejszych wiekach [Bonkáló 1990: 52-53]. Interesujący wydaje się fakt, że współcześni zwolennicy separatyzmu Rusinów karpackich rozprawiają się z mitami o fundacji Koriatowycza, wskazując je jako bazę dla ukraińskich pretensji wobec Rusi Podkarpackiej. Ich zdaniem miejscowa ludność posiada w rzeczywistości starszy „obrzęd cyrylometodejski” i „,przybyła z centralnych ziem Węgier na ich peryferie" [Timkevič 2004: 294].

Nie jest pewny rodowód innych monastyrów północnych Węgier. Prawdopodobnie najstarszym był tu klasztor w miejscowości Peri - Hruszewo na północnym brzegu Cisy. Wiadomo, że istniał przed 1391 rokiem i podlegał bezpośrednio patriarsze Konstantynopola [Timkevič 2004: 814]. Z czasem istotną rolę zaczęła odgrywać miejscowa drukarnia, która oprócz dokumentów starosłowiańskich pozostawiła zapisane cyrylicą pamiątki w języku starorumuńskim [Слободян 1994: 158]. Po upadku Cesarstwa Wschodniego monastyry północnych Węgier podlegały prawdopodobnie patriarchom mołdawskim, a być może też patriarsze Kijowa - stąd sprowadzano księgi liturgiczne [Magosci 1978: 21; Kann, David 1984: 101]. Inne bazyliańskie klasztory, które stopniowo pojawiły się w dokumentach, znajdowały się w Bukowej Górze i Krasnym Brodzie (w komitacie Zemplin), w Makowicy (pod Bardiowem w komitacie Szarisz), w Imstyczewie (Bereg) czy Małym Bereznem (Ung) [Timkevič 2004: 713-717; Magocsi, Pop 2005: 32]. Tytuły mukaczewskich władyków w początkach XVIII wieku wskazują, że swoje monastyry (z tytułem egzarchy dla zwierzchników) musiały niegdyś posiadać Spisz, naddunajskie Komarno, Sekule przy granicy z Morawami i Austrią, czy trudna dziś do zlokalizowania Javorina [Timkevič 2004: 721].

Kolejne wielkie zmiany w Królestwie Węgier nastąpiły w początkach XVI wieku wraz z inwazją turecką, konfliktami dynastycznymi i rozpoczynającym się okresem reformacji. Ostatecznie nastąpił wówczas rozpad państwa, a terytorium kraju podzielone zostało między Habsburgów, Turcję i Księstwo Siedmiogrodzkie. Zachodnia część omawianych tu północnych terenów była odtąd zależna od Habsburgów, doświadczając wzmocnienia 

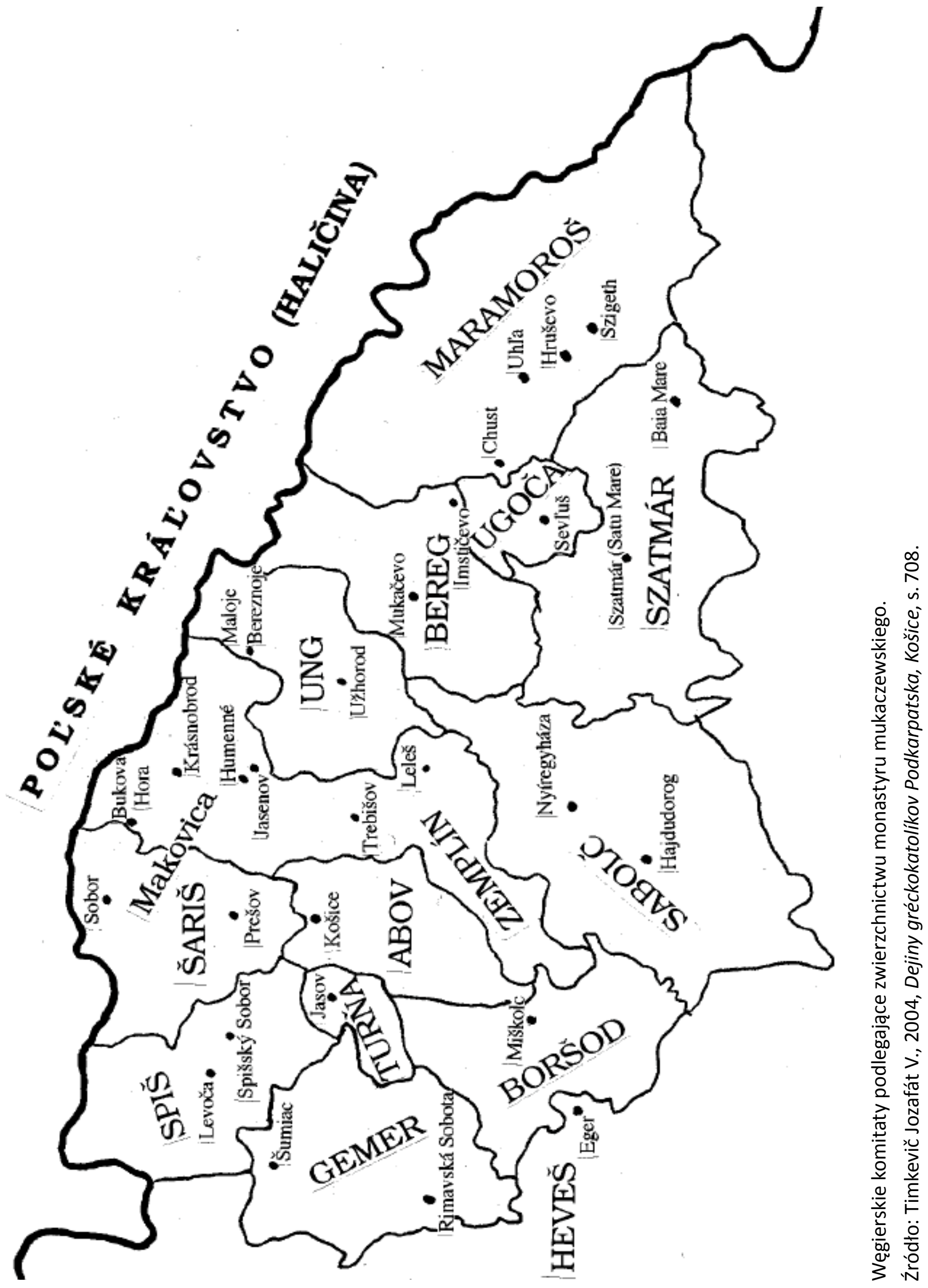
roli arystokracji i stając się obszarem walk z nowymi nurtami religijnymi. Na północnym wschodzie - powiązanym z Siedmiogrodem - panowały nieco większe swobody, a silny tu kalwinizm nie wykluczał funkcjonowania obrządku wschodniego. W habsburskich Górnych Węgrzech silny wpływ kontrreformacji na każdym polu walczących o dusze wiernych sprawił, że w 1646 roku znalazło się 63 duchownych Kościoła wschodniego, którzy podpisali z łacińskim biskupem Egeru akt Unii Kościelnej - w zamian za zachowanie obrządku i prawa do wybieralności biskupa podporządkowali się właśnie biskupstwu w Egerze. Unia rozszerzała się w następnych latach na kolejne grupy duchownych. W 1652 roku przyjęli ją mnisi z Mukaczewa - w tym czasie zależnego nie od Habsburgów, tylko od Siedmiogrodu, gdzie słaba władza wojewody pozwalała na swobody religijne. Najdłużej docierała ona jednak do położnego najdalej na wschód, ustronnego i również powiązanego z Transylwanią (jako część tzw. Partium) województwa Marmarosz. Tam ruscy duchowni przyjęli Unię dopiero w 1713 roku, a ,samodzielna ortodoksyjna diecezja przestała istnieć w 1720" [Kann, David 1984: 179]. W monastyrze Uholskim broniono się przed Unią jeszcze do śmierci ostatniego biskupa w 1733 roku, a data ta pokrywa się zresztą z momentem upadku samodzielnego Księstwa Siedmiogrodu ${ }^{8}$.

O sytuacji wiernych obrządku wschodniego w północnych Węgrzech w owym momencie dziejów wiadomo więcej dzięki dokumentacji Josifa Rog de Camelisa, mukaczewskiego wikariusza grekokatolików (tj. biskupa pomocniczego przy biskupie Egeru) mianowanego przez Rzym. De Camelis objął urząd w 1690 roku. Wizytacje oraz zakrojona na szeroką skalę akcja dokumentacji i systematyzacji parafii obrządku wschodniego sprawiły, że w 1710 roku zamiast dotychczasowych 400 parafii greckokatolickich odnotowano ich aż 1000 [Timkevič 2004: 500]. Pojawiające się nowe lokalizacje, prawdopodobnie związane dotąd były ze wspominanymi wyżej księżmi białymi ${ }^{9}$.

Początki XVIII wieku to wciąż okres zawieruch w Królestwie Węgier, walk wewnętrznych pomiędzy zwolennikami i przeciwnikami Habsburgów. Północ kraju objęło m.in. antyhabsburskie powstanie Franciszka Rakoczego. W czasie insurekcji tereny podkarpackie wyludniły się gwałtownie (Rusini masowo poparli powstańczy zryw), ale już wkrótce kolejne migracje ludności obrządku wschodniego z ukraińskich terenów Rzeczypospolitej ${ }^{10}$ wypełniły przede wszystkim górskie doliny Rusi Podkarpackiej [Куреляк 2001: 122].

\footnotetext{
${ }^{8}$ Do kościelnej władzy w Marmaroszu pretensje zgłaszali wówczas również grekokatolicy siedmiogrodzcy - używający na co dzień języka rumuńskiego duchowni podpisali swój akt Unii w 1700 roku w Alba Julia (Gyulafehérvár). Ostatecznie podjęto rozstrzygnięcie przypisujące komitat Marmarosz biskupstwu egerskiemu.

${ }^{9}$ Wraz z wciągnięciem do rejestru Camelisa następowało opodatkowanie wsi (dziesięciny kościelne przed zawarciem Unii Kościelnej nie były przez wiernych obrządku wschodniego odprowadzane).

10 Spowodowane one były wyniszczającymi walkami wewnętrznymi obozów szlacheckich, wojną północną, powstaniami na Ukrainie, ale też tragicznymi klęskami naturalnymi i zarazą.
} 
Wiele rusińskich wsi datuje swoje korzenie właśnie na ten moment. Do ósmej dekady XVIII wieku trwać miał jednak powolny upadek Kościoła greckokatolickiego. Wypaleniu i opustoszeniu uległy monastyry (m.in. Hruszewski, po części w wyniku powstania Rakoczego), a w dokumentach wsie lokowane na prawie wołoskim rejestrowane były coraz częściej jako parafie rzymskokatolickie. Rola bazyliańskich mnichów jeszcze zmalała, gdy po ustaleniach Synodu w Zamościu (Watykan rozszerzył je na unitów węgierskich) ograniczeniu uległy możliwości dożywotniego wyboru archimandryty przez mnichów. Coraz silniej w administracji wprowadzano łacinę".

Działo się tak aż do momentu, gdy wzmocnione i zjednoczone z Siedmiogrodem habsburskie Królestwo Węgier poddane zostało oświeceniowym reformom. Cały ich łańcuch, wprowadzany przez cesarzową Marię Teresę i jej syna Józefa II, likwidował m.in. wpływy Kościoła katolickiego i - nieco przewrotnie - wzmacniał unitów. W 1770 roku cesarzowa, nie oglądając się na opinię władz kościelnych (także tych w Rzymie - zależnych wówczas od absolutnych monarchii katolickich), uwolniła greckokatolickiego wikariusza Mukaczewa od pieczy biskupa Egeru [Magocsi, Pop 2005: 147]. W tym samym roku wydrukowano dodatkowo pierwszy rusiński modlitewnik - wcześniej, po spaleniu monastyrów, księgi sprowadzano tu m.in. z Kijowa. Ponieważ z Imperium Rosyjskiego „importowano” jednocześnie kult carów jako władców „,trzeciego Rzymu” i jedynych opiekunów obrządków wschodnich, to na karpackich przełęczach habsburskie wojsko dokonywało konfiskat niektórych wwożonych wydawnictw ${ }^{12}$.

Mianowany w czasie rządów Marii Teresy biskupem Mukaczewa Andrij Baczynskyj nie był bazylianinem, tylko absolwentem jezuickiego Uniwersytetu w Trnawie (założonego przez wybitnego węgierskiego myśliciela Petera Pázmányego - uczelnię przeniesiono później do Budy). Paradoksalnie to właśnie majątek jezuitów - ich zakon uległ kasacie W roku 1773 - został przekazany jako zadośćuczynienie grekokatolikom. W 1775 roku zaczęło swoją pracę seminarium w Użhorodzie (w miejsce szkoły teologicznej), a unickie biskupstwo przejęło tu zamek oraz jezuicki kościół i klasztor. W 1780 roku zwierzchnik grekokatolików przeniósł się do Użhorodu, ale utrzymany został oficjalny tytuł biskupa Mukaczewa. Wreszcie w 1781 roku cesarz Józef Il ogłosił patent tolerancyjny, a do szkolnictwa powszechnego wprowadzono języki narodowe ${ }^{13}$. Powszechność druku i działalność seminarium (gdzie nauczano po łacinie, ale także poznawano lepiej język cerkiewno-

\footnotetext{
${ }^{11}$ Z drugiej jednak strony w ręce bazylianów oddano maryjne sanktuarium w Máriapócs. Podobnie jeszcze w 1735 ma miejsce wizytacja hierarchy mukaczewskiego w żupie trenczyńskiej na zachód od Tatr!

12 Warto podkreślić, że wzmocnienie grekokatolików na Spiszu wiązało się z przekazaniem Węgrom w czasie rozbiorów Rzeczypospolitej polskiego starostwa lubowelskiego - miasto Lubowla otoczone było przez wsie rusińskie, łemkowskie.

13 Mitologizowany koniec XVIII wieku aspiruje do miana „złotego wieku” Rusi Podkarpackiej. Pod takim hasłem muzeum w użhorodzkim zamku przedstawia ekspozycję poświęconą owemu okresowi.
} 
Artykuły

słowiański) umacniać zaczęły w ruskich wsiach poczucie odrębnej tożsamości etnicznej. Swoją rolę odgrywały tu też np. coraz liczniejsze szkoły parafialne [Пензеш 1994: 36-37; Куреляк 2001: 124 i 140]. Od 1803 roku istniało również w Wiedniu, przy tamtejszym uniwersytecie, kolejne seminarium greckokatolickie - tym razem dla wszystkich obywateli monarchii. Po przerwie w działalności w latach 1848-1852, zostało ono zreorganizowane i rozbudowane.

W 1815 roku uznano, że biskupstwo mukaczewskie obejmuje nazbyt duży obszar (12 komitatów), więc dotychczasowy egzarchat koszycki przemianowano na biskupstwo - jego stolicę przeniesiono do pobliskiego Preszowa, aby w Koszycach dwa biskupstwa nie funkcjonowały obok siebie [Timkevič 2004: 683]. Do połowy XIX wieku stosunki narodowe rozwijały się na północy Węgier względnie harmonijnie, rosła też liczba rusińskich parafii czy szkół. W czasie ważnych dla monarchii Habsburgów wydarzeń Wiosny Ludów, ludność ruska pozostała niezdecydowana, ale ponosiła konsekwencje wyborów jednego ze swoich przywódców - Adolfa Dobrzańskiego współpracującego z rozwijającym się ruchem panslawistycznym i popierającego Habsburgów. Namiastkę autonomii, jaką w Ruskim Okręgu (Ruskim Kraju) ${ }^{14}$ udało się dzięki temu uzyskać, hierarchia kościelna raczej krytykowała (było to jednym z powodów dymisji Dobrzańskiego i pośrednio wpłynęło na szybki upadek tej próby ustanowienia ruskiej autonomii), np. tłumacząc sprzeciw wobec upowszechniania języka Rusinów negatywnymi skutkami dla grekokatolików używających na co dzień innej mowy - węgierskiej i rumuńskiej. Po ustanowieniu w 1867 roku dualistycznej monarchii austro-węgierskiej proces narodzin narodowego ruchu Rusinów wyraźnie osłabł (hermetyczny, zamknięty węgierski parlament wciąż reprezentował interesy właścicieli ziemskich i systematycznie odbierał prawa mniejszościom tzw. Zalitawii), a obroną ich odrębności zajmował się właśnie Kościół greckokatolicki. W Użhorodzie działało Bractwo św. Bazylego, a w Preszowie Bractwo Jana Chrzciciela - prowadziły one działalność wydawniczą i edukacyjną, ale ich rola również stopniowo zamierała [Kopyś 2001: 122]. W 1895 roku w Preszowie udało się uruchomić nowe seminarium dla duchownych unickich, ale już wkrótce wzmożona działalność funkcjonującego od 1896 roku Towarzystwa Kulturalnego Greckokatolickich Węgrów doprowadziła do kolejnego rozbicia eparchii mukaczewskiej i przypisania jej południowo-wschodniego skrawka do nowej eparchii w Hajdúdorog [Magocsi, Pop 2005: 144-145] $]^{15}$. Przyjęto tu węgierski język liturgii, nie zważając nawet na protesty Watykanu.

\footnotetext{
14 Złożonym z komitatów Bereg, Marmarosz, Ung i Ugocza.

${ }^{15}$ W 1853 roku część rumuńskich parafii przeszła pod zwierzchnictwo siedmiogrodzkiej Gherli. Nie była to jednak decyzja wynikająca z polityki hungaryzacji, ale rezultat świadomych dążeń narodowych Rumunów [Пензеш 1994: 32].
} 
Zwieńczeniem praktyk madziaryzacji w węgierskiej części monarchii - Zalitawii - była tzw. Lex Apponyi, prawo, które najpierw ograniczyło szkolnictwo w językach narodowych, a jego druga faza egzekwowana już po wybuchu I wojny światowej wymuszała zmianę języka na węgierski właśnie w kościołach i cerkwiach.

Dla dopełnienia zarysu obrządków wschodnich na obszarze północnych Węgier dodać należy, że przez cały XIX wiek aż do 1918 roku trwała konsekwentna walka z próbami odbudowy Kościoła prawosławnego, postrzeganego przez Austriaków, a potem Węgrów, jako element szerszej polityki caratu dążącego do rozbicia monarchii Habsburgów. Uwieńczeniem tej walki był słynny na całe Węgry proces w Sygiecie Marmaroskim: grupa aktywistów (w tym duchownych), która według aktu oskarżenia otrzymywała materiały propagandowe i pieniądze z ziem rosyjskich, przekonywała rusińskich chłopów z zakarpackich wsi, że „,́́więta wiara” jest pod berłem Habsburgów zagrożona oraz agitowała do przechodzenia na prawosławie. Zasądzono bezwzględne kary więzienia [Пензеш 1994: 11-13, Bonkáló 1990: 126-127]. Już po 1914 roku nastąpiły prześladowania oskarżanych o sympatie rusofilskie aktywistów, w tym licznych księży, i uwięzienie wielu z nich w szczególnie surowo zarządzanym obozie w Telerhof.

W 1918 roku greckokatolicka ludność północnych Węgier nie miała skrystalizowanego poczucia świadomości narodowej. Konkurowały tu ze sobą różne koncepcje przyszłości: rusino-hungaryzmu, związku z Ukrainą, Czechosłowacją czy Rosją. Podobnie podzielony pozostawał tamtejszy Kościół, a jego pozycja nie była na tyle silna, by nastąpił proces etnicyzacji religii. Część duchownych odwoływała się do tradycyjnej wspólnoty z Węgrami, z kolei inni sympatyzowali z Rosją ${ }^{16}$. Izolacja od wpływów prawosławia, wynikająca $z$ barier politycznych czy geograficznych, była tu jednak widoczna zarówno w ideologii, języku, jak i w kulturze, w tym choćby w stylu architektonicznym stawianych budowli sakralnych.

Decyzja o przyszłości północnych ziem węgierskich zapaść musiała wbrew oczekiwaniom przeważającej części zamieszkałej tu ludności, a reprezentowania Rusinów - popierając przyłączenie regionu do Republiki Czechosłowackiej - podjęła się diaspora w Ameryce.

Rozpad Węgier, potwierdzony w czerwcu 1920 roku w podparyskim pałacu Trianon, poprzedziła komunistyczna rewolucja Beli Kuna i restauracja Królestwa zarządzanego odtąd przez regenta Miklosa Horthyego. Północno-wschodnie tereny Królestwa zamieszkane przez grekokatolików podzielone zostały pomiędzy trzy państwa. Eparchia

${ }^{16}$ Szeroki przekrój postaw z tego okresu ukazał Paul Robert Magocsi w aneksie do książki The shaping of a national identity Subcarpathian Rus, 1978 [Magocsi 1978]. 
w Hajdúdorog pozostała w granicach państwa węgierskiego (wkrótce dołączono do niej również apostolski egzarchat w Miszkolcu, który przejął część parafii związanych dotąd z Preszowem i jedną związaną z Mukaczewem), dialektów słowiańskich używano tu jednak zaledwie w pojedynczych parafiach. Większość pozostałych ziem włączono do nowego państwa czechosłowackiego, a na dwie części podzielono jedynie Marmarosz - ok. 40 proc. jego obszaru znalazło się po 1920 roku w Królestwie Rumunii. Ziemie te, w przeważającej mierze zamieszkane przez unitów, poddano władzy biskupów siedmiogrodzkich - większość wiernych stanowili na tym terenie Rumuni oraz Węgrzy. Tylko na północy, wzdłuż Cisy i w Karpatach, granica etniczna nie pokrywała się z państwową - rumuńsko-czechosłowacką. Kilkunastotysięczna grupa Rusinów zamieszkująca okolice Sygietu Marmaroskiego (w samym mieście stanowiąca kilka procent) uzyskała jednak swoisty przywilej - powołano ukraiński, greckokatolicki wikariat, w którym znaleźli się również Rusini i Ukraińcy z innych rejonów Rumunii, m.in. z Bukowiny. Od 1930 roku rumuński Marmarosz miał własne greckokatolickie biskupstwo, a prawosławni byli tu najmniej liczni w całej Rumunii.

Ruś Zakarpacka i Preszowszczyzna znalazły się formalnie od 1920 roku w granicach państwa czechosłowackiego, a ziemie zamieszkane przez słowiańskich grekokatolików podzielono umowną i początkowo nieniosącą poważnych konsekwencji politycznych granicą wewnętrzną (rusko-słowacką). Co interesujące, niektórzy greckokatoliccy duchowni pozostali wierni Kościołowi węgierskiemu, biskup Mukaczewa, będący zwolennikiem opcji madziarońskiej, dopiero w połowie lat 20. opuścił swoje biskupstwo, przenosząc się na teren państwa węgierskiego [Magocsi, Pop 2005: 147-149]. Zarówno w Mukaczewie, jak i w Preszowie powołano ostatecznie hierarchów o innej niż madziarońska orientacji politycznej.

Choć na terenie należącym formalnie do Rusi nie wprowadzono zapowiadanej w czasie powojennego ustalania granic autonomii, nastąpiły tu zmiany. Rusini otrzymali szkolnictwo narodowe, zaczęła wśród nich krzepnąć orientacja proukraińska, a prężnie działali pod Karpatami także propagatorzy tradycyjnych więzi z Rosją. O sile oddziaływania tych ostatnich świadczy fakt, że w latach 20. nastąpił masowy transfer wiernych z Kościoła unickiego do prawosławnego. Konwertyci poddani zostali władzy Cerkwi serbskiej, choć przez pewien czas trwał konflikt ze zwolennikami autokefalii - ekumeniczny patriarcha Konstantynopola wspierał tu swojego kandydata [Magocsi, Pop 2005: 366]. Liczbę tych, którzy zmienili konfesję, szacuje się na 1/3 populacji greckokatolickiej na ziemiach Rusi.

Również w Preszowie prawosławni pozostawali pod władzą tego samego co na Rusi serbskiego zarządcy, było ich tu jednak mniej. Dynamicznie działała na Preszowszczyźnie hierarchia unicka, a aktywną politykę wspierania Rusinów i ich języka prowadził od 
1927 roku biskup Pavol Gojdić, dążący z czasem do połączenia regionu z Rusią [Magocsi, Pop 2005: 140]. W latach drugiej wojny światowej Preszowszczyzna pozostała słowacka i znalazła się w składzie współpracującego z Hitlerem państwa. Eparchia preszowska powiększyła się wówczas o fragment ziem podległych eparchii mukaczewskiej. Co znamienne, biskup Gojdić wszedł w spór z władzami słowackimi i zasłynął m.in. aktywnym sprzeciwem wobec akcji skierowanych przeciw Żydom [http://test.grkatpo. sk/?pavol_peter_gojdic].

Na Rusi Zakarpackiej Węgrzy przejęli pełnię władzy cywilnej w marcu 1939 roku, a drugi arbitraż wiedeński z sierpnia 1940 roku skutkował przyłączeniem do ich państwa także rumuńskiego Marmaroszu. Struktura organizacyjna kościoła na tych obszarach pozostawała w latach światowego konfliktu skomplikowana. Tereny należały wprawdzie do Węgier, ale administratorami pozostali dotychczasowi, rumuńscy i ukraińscy, biskupi greckokatoliccy (administracja podzielona była między biskupstwa mukaczewskie oraz marmaroskie ze stolicą w Baia Mare). W przypadku prawosławia serbski eparcha zarządzał jednocześnie ziemiami państwa słowackiego i podległej Horthyemu Rusi. W 1944 roku większość hierarchów prawosławnych poprosiła o przejęcie zwierzchnictwa patriarchat moskiewski, do czego też ostatecznie doszło (prawosławni z Preszowszczyzny w 1951 roku przeniesieni zostali do Czeskiego Kościoła Autokefalicznego).

Republika Węgierska powołana w lutym 1946 roku na miejsce Królestwa Węgier przyniosła kres więzi administracyjnych Kościoła węgierskiego i terenów zamieszkanych przez Słowian. Kościół greckokatolicki na Węgrzech, w którym pozostały jedynie pojedyncze parafie pamiętające o słowiańskich korzeniach, działał przez cały okres rządów komunistów, funkcjonowały eparchia w Hajdúdorog i egzarchat w Miszkolcu.

Losy grekokatolików na Zakarpaciu, będącym odtąd częścią Ukraińskiej SSR oraz w Rumunii i Czechosłowacji, potoczyły się podobnie, a zarazem inaczej niż w państwie węgierskim. Wszędzie dokonano likwidacji Kościołów unickich, przekazując ich majątek prawosławnym. Na Słowacji i Zakarpaciu ${ }^{17}$ Kościół zszedł do podziemia, w Rumunii zniknął zupełnie. Hierarchia prawosławna wszędzie podlegała ścisłej kontroli władz państwowych.

W 1968 roku wydarzenia praskiej wiosny przyniosły cofnięcie zakazu działania i częściową odbudowę Cerkwi unickiej w Czechosłowacji. W Związku Radzieckim, a przede wszystkim w Rumunii na reaktywację Kościoła greckokatolickiego trzeba było poczekać do upadku ,żelaznej kurtyny”.

\footnotetext{
17 Na Słowacji aresztowano biskupa Gojdicia i mimo jego niezłomnej postawy w czasie wojny zarzucono mu kolaborację; na Zakarpaciu losy grekokatolików były szczególnie tragiczne, komunistyczne służby specjalne zamordowały mukaczewskiego władykę Teodora Romżę.
} 


\section{Bibliografia}

Bonkáló Sándor, 1990, The Rusyns, New York: Columbia University Press.

Felczak Wacław, 1966, Historia Węgier, Warszawa: Zakład Narodowy im. Ossolińskich.

Kann Robert A., David Zdeněk V., 1984, The Peoples of the Eastern Habsburg Lands, 1526-1918, Washington: University of Washington Press.

Kopyś Tadeusz, 2001, Kwestia narodowościowa na ziemiach Korony Świętego Stefana w latach 1867-1918, Kraków: Wydawnictwo Promocji Powiatu, Miasta i Gminy „Promo”.

Куреляк Васіле (Kurelak Wasiłe), 2001, Українці Румунської Мараморощини, Львів.

György Györffy, 2003, Święty Stefan I - król Węgier, Warszawa: Rytm.

Labuda Gerard, 2004, Szkice historyczne X-XI wieku: z dziejów organizacji Kościoła w Polsce we wczesnym średniowieczu, Poznań: Wydawnictwo Poznańskie.

Labuda Gerard, 1988, Studia nad początkami państwa polskiego, t. 2, Poznań: Wydawnictwo Naukowe Uniwersytetu im. Adama Mickiewicza.

Leśny Jan, 1987, Konstantyn i Metody apostołowie Słowian. Dzieło i jego losy, Poznań: Księgarnia Świętego Wojciecha.

Magocsi Paul Robert, Pop Ivan, 2005, Encyclopedia of Rusyn History and Culture, Toronto - Buffalo - London: University of Toronto Press.

Magocsi Paul Robert, 1978, The shaping of a national identity Subcarpathian Rus 1848-1948, Cambridge Massachustetts - London: Harvard University Press.

Пензеш Василь (Penzesz Wasyl), 1994, Iсторія Української Греко-Католицкої Церкви в Мараморощині й иілій румунській державі, Львів.

Слободян Василь (Słobodian Wasyl), 1994, Церкви Українців Румунії, Львів.

Timkevič Jozafát V., 2004, Dejiny gréckokatolíkov Podkarpatska, Košice.

Serwis internetowy słowackiej Cerkwi Greckokatolickiej http://test.grkatpo.sk/?pavol_ peter_gojdic (dostęp 11 IX 2012).

Історія України IX-XVIII ст. Першоджерела та інтерпретації

http://litopys.org.ua/litop/lit25.htm (dostęp 11 IV 2013).

\section{Eastern rite churches in the northern areas of the Kingdom of Hungary - historical outline}

The article provides an overview of the history of Eastern rites in the northern areas of the Kingdom of Hungary, focusing chiefly on the historical-graphic position of Karpatho-Rusyn The lands belonging today to Slovakia and Carpathian Ukraine from the Middle Ages, and the division of Christianity into two branches, were populated by a large group of believers who did not recognize the supremacy of the Roman Church. It was only in the seventeenth and eighteenth centuries that the power of the popes was recognized in exchange for the preservation of their traditional, religious rites. 
The text reconstructs the specific societal fate of the region. The article discusses the issues of the colonization of the territory, the history of the local church institutions, the fate of this area of Europe during the times of the Reformation, the establishment of the union between the Orthodox Church and Rome, and finally the era of the emergence of modern nationalisms. This study clarifies the discourse of today's social and national activists. It reconstructs contemporary narratives and myths and proposes an overview of the creation of the cultural and political amalgam on the slopes of the Carpathian Mountains while asking questions concerning the origins of religious syncretism.

\section{Key words:}

Ruthenians, Carpathian, Hungary, monastery, rite

\section{Słowa kluczowe:}

Rusini, Preszowszczyzna, zakarpacki, grekokatolicy, monastyr 